\title{
Do stakeholders in Denmark know about social investment within long-term care?,
}

\author{
Greve, Bent
}

Published in:

Journal of International and Comparative Social Policy

DOI:

10.1080/21699763.2018.1465447

Publication date:

2018

Document Version

Peer reviewed version

Citation for published version (APA):

Greve, B. (2018). Do stakeholders in Denmark know about social investment within long-term care?, Journal of International and Comparative Social Policy, 34(2), 127-139. https://doi.org/10.1080/21699763.2018.1465447

\section{General rights}

Copyright and moral rights for the publications made accessible in the public portal are retained by the authors and/or other copyright owners and it is a condition of accessing publications that users recognise and abide by the legal requirements associated with these rights.

- Users may download and print one copy of any publication from the public portal for the purpose of private study or research.

- You may not further distribute the material or use it for any profit-making activity or commercial gain.

- You may freely distribute the URL identifying the publication in the public portal.

\section{Take down policy}

If you believe that this document breaches copyright please contact rucforsk@kb.dk providing details, and we will remove access to the work immediately and investigate your claim. 


\section{Introduction}

Social investment has increasingly come on the agenda in recent years (European Commission, 2013). This can, at least partly, be ascribed to that there has been a need for trying to set at new focus on public sector spending in the wake of the financial crisis, by pointing to the possible positive impact of public sector expenditures. This instead of only looking at expenditures as something, which needs taxes and duties in order to finance welfare services. This builds also theoretically on previous discussions on new ways for the welfare states in the wake of earlier crisis, such as Jenson, 2009, Taylor-Gooby, 2008, and, further Morel et.al., 2012.

At the same time, a trend in long-term care policy in Denmark has been to support independent or assisted living in one's home as long as possible or as labelled now in one's own life. One explanation for the growing interest on the social investment as a paradigm in the field of LTC is the possible expected pressure on social spending because of the growing number of elderly. Social investment is further expected not only to have a direct economic impact but also to improve wellbeing (Kolov and Tassot, 2016).

Social investment can be seen as a new paradigm in social policy, in contrast to Keynesian and Liberal understanding of the development of welfare states. It can be argued to be in contrast to a neoliberal approach, for a description of neoliberalism (Piven, 2015). An abundant number of books and articles on the subject have been published in recent years. The concept is although not completely new (Midgley, 1999, Smyth and Deeming, 2016), and may well be argued to be a movement back to the ideas about the productive welfare states (Hudson and Kühner, 2009). Recent years has also seen attempts to measure and analyze whether and how spending on social investment has developed (Kuitto, 2016, Ahn and Kim, 2015).

The aim of this article is three-folded. It will focus on social investment as a paradigm and as idea, however with a view to a specific policy area often not included as one where social investment is discussed, i.e. long-term care. This will be done in Section 2. This will be followed by some methodological reflections on how to analyse and understand the concept of social investment in LTC in section 3, including the combined approach here by use of existing analysis and focus group interviews. 
Section 4 turns towards what can be considered as social investment in long-term care in Denmark. The focus will be on issues such as rehabilitation, re-enablement, welfare technology and prevention, see also Greve (ed.) 2017. This given the aim of being able to aging in place, which is not only a Danish approach, but also an international development (Deusdad, Pace and Anttonen, 2016). Section 5 will then based upon a focus group interview conducted in January 2017 analysis stakeholders view on and whether they are aware of social investment both on a paradigmatic and ideational level. The article shows that despite the concept is not embraced by stakeholders or by the state, there has been included in the policy-making issues, which can be considered social investment. Thus, theoretically this point towards that a new paradigm need not always to be recognised by stakeholders in order to have an impact on policy development. However, it also indicates that ideas matter (Beland, 2005, Beland, 2018).

There will always be delimitations of an article. Here this includes possible ethical issue related to the use of welfare technology, see Hofmann, 2013. Another delimitation is the issue of prevention and rehabilitation across Europe, see instead Kümpers et. al. (2010) and Greve, ed. (2017). This is not a comparative study, although few remarks will be made at the end, given that a universal welfare state as the Danish might have a different development than countries from other welfare regimes.

\section{Social investment and long-term care}

The European Commission social investment package from 2013 do barely mention long-term care and only that it varies in size and type among the European countries (European Commission, 2013), albeit also mentioning rehabilitation. However, a study on Social Investment in Europe for the commission points out the idea of that LTC is a new social risk and that the objectives of LTC in social investment is "prevention from disabilities and rehabilitation on the one hand, improvement in the quality of care staff on the other hand” (Bouget et. al., 2015, p. 30). Further, it seems that all budgeting officials within the EU-countries find impact analysis important and that LTC to a certain extent can help in better employability and reduced inequalities (European Commission, 2016). Still another policy implication of the idea of social investment is that it has opened new ways and a possible positive role for social policy (Mahon, 2013). Overall, however, rehabilitation does not seem to be effective for older people who are long-term care residents 
(Crocker, T. et. al, 2013) which may explain why the concept as such is only limitedly embraced among the actors in the field.

That there has been a drive towards social investment can be seen from the many articles on the subject. For some scholars, it has been on the way since the late 1970's as an emergent concept (Kersbergen and Hemerijck, 2012). Social investments in old age care are albeit only a more limited part of this development: "In general, policy developments here are reactive, responding to the growing need rather than driving forward particular agendas as in the case of childcare” (Daly, 2012, p. 631). Day-care is, like an investment in the human capital, more often mentioned as an example of social investment (Hudson and Kühner, 2009). Further, that change in LTC in recent years especially has had a focus on reducing spending and less on exploring the possible applications of social investment. There is also the use of several other words to show and explain the development such as new welfare state, new risk welfare, active social welfare, the 'Third' way (Taylor-Gooby, Gumy and Otto, 2015).

Social investment looks into and has had a focus on the development of human capital, improving qualification and life-long learning; however, some would argue also minimum income safety nets (Hemerick, 2015). Criticisms of the social investment idea has pointed to that it has lacked a focus on disadvantaged groups on the labour market (Nolan, 2013), too few resources on combating poverty (Vandenbroucke and Vleminckx, 2001), and that social redistribution are becoming less pro-poor (Cantillon, 2011). Further that it seems that there might be some linkages between the new focus on investment and the stagnating or increasing poverty (Vliet and Wang, 2015). Finally, that the focus on LTC to a large degree has been on the supply side (Mahon, 2013), and that it can be interpreted as part of the activation turn (De Deken, 2014). However, not all find evidence for that the impact has implied reduced egalitarian spending (Vaalavuo, 2013). Finally, that it looks like to be (based upon data from 2001-2007) better in promoting job than reducing poverty (Taylor-Gooby, Gumy, Otto, 2015).

Besides that LTC not has figured prominently in the analysis of the development of social investment, it is further so, that the commission in the first annual growth survey saw pensions and health care as a burden (Sabato and Vanhercke, 2014). Given that health care often is strongly interlinked to long-term care this indicates a need for probing into an analysis of the connection between LTC and social investment 
Although when measuring of what constitutes social investment it is not always clear which social policy fields to include, however parental leave, elderly care, childcare, active labour market policies and primary and secondary education can be witnessed to be included (Vandenbroucke and Vleminckx, 2011, Vliet and Wang, 2015). Analysis is further often done on the overall macro-level and with less focus on what is changed within the system and impact on the micro level.

Still, the focus on investments that - like day care - might enable carers also to be in the work-force is an argument for that at least part of spending or changes in spending on LTC can be considered social investment (De Deken, 2014).

Stakeholder's views are important as they can reflect view and ideas, that might be important for social policy’s development, see Beland (2005 and 2018). Theoretically, social investment can be interpreted as an idea, some would even argue paradigm, where stakeholders viewpoint on, and knowledge of this idea might influence the development of a specific policy field. Furthermore, stakeholders view on what quality is in a specific field is important in order to conduct different types of analysis, such a SROI (Costa, 2017), so that how they perceive a system is an important issue.

\section{Methodological considerations}

This article is a cased based study using a universal welfare state as Denmark with a, compared to other countries, high level of spending (Greve ed., 2017, Greve and Poskute, 2017). Thus seemingly at the outset a good case to look into examples of social investment in long-term care. It is albeit not a critical case. The analysis is done by searching for information on and studies related to what can be considered social investments in long-term care, as this can also inform on the possible impacts of social investments within the field. The case study is looking into a specific field, LTC, due to, as also argued above, that this field is under scrutinised in international analysis of social investment. This article is based upon a mixed method approach (Leech and Onwuegbuzie, 2009). This is by using existing studies, which has been searched for using words like social investment, rehabilitation, re-enablement and welfare technology (in Danish as the focus has been on studies directly related to the Danish universal Nordic welfare state). This search was combined with use of a focus-group interview with central stakeholders in the Danish welfare state, which was conducted in January 2017. In appendix one is shown who participated in the focus-group interview. 
The focus group interview support the other aim of the article to probe into whether the idea was known and used by stakeholders in the field. This while at the same time trying to analyse whether that despite the concept is not well known among actors, then it is strongly integrated in the development of the Danish welfare state, and also within LTC. The focus group was conducted based upon a common framework for several countries in order to be able to also to conduct a comparative analysis. The aim of the focus group was to get central stakeholders to participate. This aim was nearly achieved as not only interest groups, but also people working in the sector and people who have researched on long-term care were involved. It would have been good also to have some from the state and local administration. This was unfortunately not possible. Albeit with one working in a municipality and with the organisation and researchers well informed on the local issues this seems to be less of a problem. Furthermore, the central policy levels view are reflected in recent changes in legislation and official documents, see also next section, so in this way interviews with central stakeholders are more important in order to depict what and how this relates to a social investment perspective, and, how this can inform about what is central aspects to be aware of. Therefore, one can argue that all relevant stakeholders has been included.

Thus, qualitative data is combined with secondary data analysis, thus aiming at presenting the question on the idea and its possible influence on the welfare state development. A few quantitative data on types of activities resembling social investment, see in Section 4, is also included as background. However, the article will not present data on spending, development herein and comparison to other countries, see instead, Greve, 2017.Social investment in LTC in Denmark

Social policy has been argued for a long-time in Denmark, at least officially, to have a social investment profile. In a publication from the Ministry of Social Affairs on Social Investment from 2000 it is even argued that participation of both men and women in the labour market is high and that "one supporting factor is, that there exists a developed care for the elderly and people with disabilities” (Socialministeriet, 2000 p. 94, own translation).

Despite this official early view, and, as will be shown later in Section 5, the idea of social investment is not really integrated in the stakeholder's view. However, at the same time there is by now several legal requirements to do things that can be considered social investments in the Danish welfare state. There has been, in recent years, increased emphasis on using instruments and approaches that can be considered social investments, such as use of welfare technology, 
preventative initiatives and rehabilitation. Social investment as a potential perspective is thus not new, and seems even to be growing in Denmark (Mandag Morgen, 2017), albeit not within longterm care, but more related to children and the use of the so-called Skandia-model. Local municipalities also seem to be prepared to do social investment as a way of trying to get vulnerable people back to the labour market. Part of the social investment related to children is inspired by the famous article by Heckman, 2006.

Part of the social investment approach is in fact enshrined in the legal rules. This is the Law on Social Service §83a, which was implemented from first of January 2015. It has the intention and obligation for the local municipalities to try to rehabilitate in such a way that the elderly is able to take care of him/herself if the rehabilitation as expected is able to reduce or even eliminate the need for support.

In the same law $\S 79$ obliges municipalities for those elderly above the age of 80 to make preventative home-visits. It is not obligatory for the elderly to accept it, and, the municipalities do not need to do it for those in homes for the elderly. There can be variation in age group where one starts, and how often it is done - however, it is at least once a year. In those homes where the elderly already gets home help, it is optional for municipalities to offer this. They have also been obliged from 2016 on to do it for those aged 65-79 in the risk of reduced functional abilities. Finally, § 112 gives the municipalities possibilities for supporting with help-remedies, including changes in private homes, in order to make it possible for an individual to stay longer in the persons own home.

Thus, overall this point to that the state and central decision-makers have included activities that can be considered social investments in the field of LTC such as rehabilitation and prevention, but also see later by investing in welfare technology. This is expected to increase the quality of life for the elderly and reduce the possible economic pressure on the cost of long-term care due to increase in the number of elderly people.

Part of these reforms has come by evaluating some activities as potential examples of social investments. One municipality tested the rehabilitation approach. A report evaluated the rehabilitative efforts in a municipality in Denmark, which since has given name to the model for rehabilitation in Denmark (e.g. Fredericia-model). The report about this experiment estimated that rehabilitation reduced cost per service user by $13.9 \%$. Of those participating (408 patients) in the 
first years: $45 \%$ needed no help after the intervention, 40 \% needed less help and $15 \%$ the same as in the ordinary home help care (Kjellberg, P. et. Al., 2011).

That there might be savings, albeit not always in the first year, can also be seen in studies on welfare technology. For example, a business case shows that the payback period for an investment is low for door-automation (3 years), curtain-automation (3 years), hoist in ceilings (2 years), different toilets ( 1 to 3 years dependent on how many functions), whereas it takes 11 years to reach a break-even point for a robot cleaner (Andersen et. Al., 2016). Given that technology develops fast, this might be even shorter in the years to come. The positive economic outcome of investment in rehabilitation is also shown in other studies (Kjellberg and Ibsen, 2016).

Recent years has seen a strong increase in different kind and use of welfare technology. A recent overview presented by the municipalities organization (KL), thus as headline had the following: Welfare technology has become commonplace in the municipalities (http://www.kl.dk/Momentum/momentum2017-5-1-id220510/, accessed March 15, 2017). The municipalities thus overall are implementing technology in most places where it is expected to yield a positive outcome for the elderly, the long-term care workers - and for the economy in the municipalities. The focus on welfare technology has been promoted also by the state as the municipalities as part of the central economic agreement are expected to be able to reduce overall spending on LTC by investing in welfare technology.

The active ageing approach (e.g. aiming at that we live longer in a better health) has also been seen as reducing the pressure on the local municipalities’ budgets, and, thus prevention in other areas than LTC might reduce the future cost on LTC, albeit budgets for these activities are not counted within the LTC system. Whether it in total reduces overall public sector spending or postpone it to a later age is further a complication if one wants to measure the impact of social investment.

Overall, the development points towards that the idea of social investment is in fact a perspective integrated in the way spending in LTC has been developing with a stronger focus on prevention, rehabilitation and re-enablement of the elderly in Denmark.

\section{Stakeholders and social investment}

This section presents the analysis of the conducted focus-group interview - especially with a focus on social investment albeit that during the interview several different issues where raised. In order 
to depict and understand the focus on social investment it is important to know what works and what does not work and probe into whether the participants were aware of the concept of social investment. The structure follows the questionnaire used for the interviews in all countries organizing focus-group interviews. The participants has been sent a summary of interview in order to ensure and been given an option to raise their voice whether they are in agreement, disagreement or whether they found that something were missing. They have also given their consent to participate in the focus group interview, and whether they would accept that their name and affiliation is attached to and used in analysis.

There was fundamentally a positive view of the Danish system of long-term care provision. Although, many of the participants were very critical towards different aspects of the contemporary system, then there was a general agreement that elderly people were better off under the Danish system of long-term care provision than in many other European countries. This was particularly due to the universal character of the public long-term care system, but also due to the underlying principles of professional and preventative home care. The effects that this system have had on the opportunities for women to enter the Danish workforce was also highlighted as an important aspect. Given that increased participation on the labour market also can be considered as investment (as with day care for children) thus this implicitly shows that part of the LTC also by stakeholders is considered as social investment and a positive issue.

When looking into possible success stories, the focus group interview emphasised professional, highly educated, preventative, interdisciplinary and holistic long-term care. If this is seen as a quality this also points to that investment in education and high level of professional care can be argued to be social investment within LTC, where the benefits lies in the higher quality of care.

Furthermore, the focus group was in agreement of the need for long-term care that not only focuses on practical and measurable tasks, but rather also includes a broader array of emotional, social and practical help. As an example, this type of care would not only be attentive to as one person argued “maintaining and rehabilitating the right arm of an elderly in order for them to vacuum again”, but rather would also have greater ambitions of giving the elders a worthy and meaningful everyday life that also includes social relationships, meaningful activities, etc.

Furthermore, one of the participants pointed out the importance of being aware that quality of longterm care is not always something measurable (or at least is something very difficult to measure), as it lies not only in the care provided, but also in the social relationships and interactions, as well as 
the feeling of worthiness and respect that the elders feel. This might, as the quality of the professional care, also constitute a problem in the measurement of the outcome of LTC.

Quality of care is in line with the idea of a holistic long-term care. In this regard, the importance of organisational interconnectedness and interdisciplinary care was stressed by the focus group. An example of this comes from the municipal of Silkeborg, where the hospital and the municipal longterm care provider were connected in a fashion that ensured a smooth and proper transition and rehabilitation from the hospital bed to the nursing home/home care. Another example of this comes from the municipal of Aarhus, where the municipal long-term care providers concerned with preventative initiatives work side-by-side with the municipal volunteer coordinator to ensure proper and sufficient coordination between volunteering citizens and the needs of preventative care and activities.

Many participants also mentioned the strength of the extensive long-term care network in Denmark. There are several of organisations both on a governmental, non-governmental, local and national level that all are highly interconnected and implemented into the provision and development of the long-term care system. A success story of the interconnectedness of this network was mentioned in regards to the digitalisation of the public bureaucracy. In the transition of digitalisation, the government established cooperation with the large interest groups of elders, which resulted in that the government allowing some elders to abstain from the digitalisation. On the other hand, in return, the interest groups then took to task to educate and involve as many elders in the digitalisation. This resulted in a rather successful integration of long-term care recipients in the digitalisation as possible of the public bureaucracy that otherwise could have entailed many organisational problems.

Additionally, there were also mentioned alternative success stories during the focus group. One of the members for example talked about a civil housing project that was established to organise mutual care amongst the elders in a collective fashion. This followed the consensus of the focus group that stressed the importance of the elders having sufficient social activities in their everyday life. Activity during daily life was seen as an aspect of healthy ageing and thereby indirectly also as a good long-term care system if it could prevent further reduction in functional abilities. This also is an example of the possible blurring line between care and prevention.

An issue that the group raised was the departmentalisation and outsourcing of care tasks that have been occurring throughout the Danish long-term care system. More concretely, this refers to the 
breaking down of the total care act to smaller care tasks that is orchestrated by different agents. This has, to the eyes of the focus group, had detrimental effects both for the quality of care that elderly have received, but also decreased the job satisfaction of the care professionals. The main problem is that it incentivises the caregivers to simply perform the given practical tasks each caregiver have been given, and makes it very difficult for them to provide holistic care.

In line with the issue of departmentalisation of the long-term care provision in Denmark, another topic the focus group mentioned several times was the role of loneliness and social isolation amongst elders in need of long-term care. Particularly in the Danish system of long-term care, it was argued by various members of the focus group that the way in which we distribute care may in fact lead to increased loneliness and social isolation. This is partially due to the fact people are enabled to stay in their own home for so much longer than without the home care of the Danish system, yet do not receive help to maintain or establish a social network, as the care remains to be insufficient in a social aspect. As such, a critique of the Danish system was that it, as phrased by one of the participants: "rehabilitates to loneliness", and, as also noted by one of the participants, considering the health risks of loneliness, then it seems very detrimental that the current system refrains from supporting the social network of lonely elders to a sufficient degree, which all too often is left to volunteers.

A concrete example trying to change the situation of loneliness was mentioned. This being the introduction of vouchers enabling the elderly in need of care the option to "save" hours so that they could sometime perhaps visit others, go shopping or participate in activities with support of the home help. Thus if this helps in reducing loneliness, and, thus also reduces the need for care, then this can also be considered a social investment.

Another key critique of the Danish long-term care system was that although the directives of the government within long-term care often are ambitious, then the local implementations in the individual municipalities often differentiate severely. To some of the participants, then this was arguably because of the abstract and broad directives that allow the municipalities a lot of autonomy in determining how these directives should be interpreted in the given municipal. Although positive aspects of decentralisation of decision making was also mentioned such as close to the citizens in need of support. A general problem in this regard is that there is no clear central outline about what quality is and how it can be measured within the Danish provision of long-term care. The variation 
in the economic options for local municipalities and the risk of variation in service available was also seen as an issue.

The focus group also highlighted the need for additional education of caregivers. This was additionally mentioned in regards to the usage of welfare technologies that, to the record of the focus group, often becomes useless, as caregivers remain inexperienced on how to use them. This implies that social investment needs not only to be in use of new technology, but also in training and education.

\subsection{This part of the analysis was important in order to depict and relate to issues that can} be important aspect to include when looking into social investment in LTC, and the ability to conduct analysis of social investment within the field. Social Investment as concept

Probing more directly into the concept and understanding of what social investment is, the stakeholders overall expressed a very positive stance on the idea of social investment, but, notably, then it was primarily the academic participants that commented on the concept in itself. Seemingly, no strong perception of the knowledge of the concept available as a specific idea, however, strong knowledge on how spending in different part of the long-term care sector could improve the quality of life, healthy ageing and also be important for relatives, friends and voluntary groups, as indicated in the previous section. This could also include options for better labour market participation for carers, especially women who even in Denmark still is the main informal provider of care, also sometimes for elderly parents in need of support.

Social investment was linked to various elements. Almost all of the participants were focused on the importance of public investment in helping elders to establishing and maintaining a social network, social engagement and social relationships, see also the voucher example above. This was throughout a very important element of a successful long-term care provision.

Others also connected the idea of social investment to a larger degree of involvement of the individual elder in their rehabilitation and care. Transportation and access to transport seen as important in order to ensure contact, thus pointing to that social investment can be broader than what is considered being a central issue directly in relation to long-term care. However, pointing to that whether one has a broader or narrower perspective on what influences long-term care this will influence policies and policy areas that might come into play. 
The voluntary sector was pointed to as an element that could help in relation to loneliness, albeit with a clear view to that this should help in especially social activities, whereas the professional staff should do the care work.

Although a general positive attitude towards the idea of social investment, then some of the participants also voiced concerns about the fact that ideas of social investment may rely too heavily on rehabilitation and "repair-solutions" rather than preventative measures. A focus on prevention could include awareness of food and physical exercise, and support in achieving a healthy ageing.

One of the things that were, in general, agreed upon amongst the focus group was the need for equal access and choice for all elderly to all long-term care facilities. As the negative consequences of division linked to inequality was seen as detrimental. This again raised the issue of whether the decentralised Danish welfare state always achieved this goal as there can be local difference, at least on the margin, due to different local priorities and local economic options.

Elderly councils in the municipalities were also argued to be a resource for influence for the elderly on the local initiatives, and, thus a way to ensure citizens voice in the what would be a good content and delivery of long-term care.

Overall, the focus group interview points to that the idea of social investment can be important for long-term care, and this even without using or knowing the details of the concept. The interview further emphasizes that the traditional understanding of a narrow understanding of what is longterm care, e.g. highly focusing on the care in itself, can be a too limited approach as also other policies influence the need for and the functioning of long-term care and quality of life of citizens.

Whether and how this can be measured is an open question. Prevention has ( Debels and Hoyweghen, 2018) always been an issue within social policy, but has often been difficult to persuade policy makers to do as this might take time before the investment is paid back. Further, that active ageing perhaps is needed long-before people in fact are ageing, and, also that non-care issues, such as loneliness can influence the need for care.

The main way the stakeholders viewpoint has had an impact can be argued to be that the demand for better quality and also support to that elderly should stay as long as possible in their own life, has implied by policymakers a stronger focus on and including in the legislation preventative measures (home-visits) and ability to live an independent life (re-enablement and rehabilitation). 
Finally, no one seems to be worried about that a social investment perspective would take focus and initiatives away from the elderly despite that the outcome of an investment in this field might be lower than when investing in young people.

\section{Concluding remarks}

Denmark has a long tradition for universality, comprehensive and egalitarian approach to welfare benefits in cash and in service, including being labelled a social service state. Thus having a relative large social service state is not new, and, therefore in relation to LTC there has been a long tradition for state involvement. The demographic pressure has also been an issue in relation to a move towards the use of rehabilitation, prevention and implementing of welfare technology and thereby, albeit mainly indirectly, got an increased focus on social investment. New ways of financing and delivering welfare state services has also come more into focus in recent years.

Despite that this indicates use of a social investment perspective in LTC in the Danish welfare state the interviewed stakeholders did not seem to be aware of the concept, however when discussed they were seemingly in agreement with the idea and several of the implemented policies that can be understood in the light of social investment. Thus, on the one hand this indicates that social investment is part of the welfare strategy in LTC in Denmark, and could be endorsed by the actors. However, it is still also mainly an idea on the overall level, but has not moved down to be fully embraced by the stakeholders.

Social investment in the field of LTC can be expected to be more developed in a universal welfare state like the Danish - also due to that Denmark comparatively spends more from the state within the field of LTC. At the same time the interview and existing studies points to a role for social investment in the sense that use of new approaches, new technologies might reduce the pressure on the long-term care system, and that it can be important for caregivers. Further, that the boundaries of what to interpret as social investment related to a specific policy area can be difficult, thus, for example, healthy ageing might need to start very early and transport system is also for other than the elderly.

Overall, the policy development together with the stakeholder interviews points towards that the idea of social investment has influenced the development, and, also that such a concept can have an impact indirectly even when not acknowledged by the stakeholders as such. Stakeholders might 
finally have endorsed policies because of using a social investment approach without being aware of that, this is the case, and, they can therefore as also shown in the interview be positive towards these changes and thereby social investment when informed about the ideas behind the development.

Finally, that if investment that influence LTC is made within different parts of the welfare state there might be a need for transferring resources from area to another. 


\section{Literature}

Ahn, S. and Kim, S. (2015), Social investment, social services and the economic performance of welfare states. International Journal of Social Welfare. Vol. 24, pp 109-119.

Andersen, D. et. Al. (2016), Velfærdsteknologi i plejeboliger, medarbejder og økonomisk perspektiv. København, SFI.

Beland, D. (2005), Ideas and Social Policy: An Institutionalist Perspective. Social Policy \& Administration, vol. 39, no.1, pp. 1-18.

Beland, D: (2018), How Ideas Impact Social Policy, in Greve, B., The Routledge Handbook of the Welfare State, $2^{\text {nd }}$ edition, Oxon, Routledge.

Bouget, D. et. al. (2015), Social Investment in Europe. A study of national policies, Brussels, European Commission.

Cantillon, B. (2011), The paradox of the social investment state: growth, employment and poverty in the Lisbon era. Journal of European Social Policy, vol. 21, pp. 432-449.

Costa, M. (2017), Social return on investment (SROI), including elements on cost-benefit analysis in Greve, B. (ed)., Handbook of Social Policy Evaluation, Cheltenham, Edward Elgar.

Crocker, T. et. Al. (2013), Physical rehabilitation for older people in long-tem care (review), Cochrane Database Syst Rev, 2. DC004294

Daly, M. (2012), Making policy for care: experience in Europe and its implications in Asia. International Journal of Sociology and Social Policy, vol. 32, no. 11/12, pp. 623-635.

Debels, A. and Hoyweghen, I (2018), Prevention: The cases of social security and health care in Greve, B. (ed.), The Routledge Handbook of the Welfare State. Oxon, Routledge.

De Deken, J. (2014), Identifying the skeleton of the social investment state: defining and measuring patterns of social policy change on the basis of expenditure data in Cantillon, B and 
Vandenbroucke, F. eds. (2014), Reconciling Work and Poverty Reduction, How Successful Are European Welfare States? Oxford, Oxford University Press.

Deusdad, B., Pace, C. and Anttonen, A. (206), Facing the Challenges in the Development of Long-Term Care for Older People in Europe in the Context of an Economic Crisis. Journal of Social Service Research, vol. 42, no.2, pp. 144-150.

European Commission (2013), Social Investment Package, Brussels, EU.

European Commission (2016), Joint Report on Health Care and Long-Term Care Systems \& Fiscal Sustainability. Institutional Paper 037, Brussels, European Commission.

Greve, B. (ed.) (2017), Long-Term Care for the Elderly in Europe. Development and Prospects, Oxon, Routledge.

Greve and Poskute, (2017), Long-term Care in Denmark and Lithuania - A Most Dissimilar Case. Social Policy \& Administration, vol. 4.

Heckman, J. (2006), Skill Formation and the Economics of Investing in Disadvantaged Children.

Science30 Jun 2006 : 1900-1902

Hemerick, A. (2015), The Quiet Paradigm Revolution of Social Investment, Social Politics, vol. 22, no. 2, pp. 242-256.

Hofmann, B. (2013), Ethical Challenges with Welfare Technology: A Review of the Literature. Sci Eng Ethics, vol 19, pp, 389-406.

Hudson, J. and Kühner, S. (2009), Towards productive welfare? A comparative analysis of 23 OECD countries. Journal of European Social Policy, vol. 19, no. 1, pp. 34-46.

Jenson, J (2009), Lost in Translation: The Social Investment Perspective and Gender Equality, Social Politics: International Studies in Gender, State \& Society, Volume 16, Issue 4, pp.446-483, https://doi.org/10.1093/sp/jxp019.

Kerbergen, K. and Hemerijck, A. (2012), Two Decades of Change in Europe: The Emergence of the Social Investment State. Journal of Social Policy, vol. 41, no. 3, pp. 475-492.

Kjellberg, P.K. et. Al. (2011), Fra pleje og omsorg til rehabilitering. Erfaringer fra Frederica Kommune, København, DSI. 
Kjellberg, J. and Ibsen, R. (2016), Rehabiliterende hjemmepleje efter Roskilde-modellen. En analyse af de økonomiske konsekvenser af Roskilde-modellen for rehabilitering. København, KORA.

Kolev, A. and Tassot, C. (2016), Can investments in social protection contribute to subjective wellbeing? A cross-country analysis. OECD Development Centre, working paper no. 332., Paris, OECD.

Kuitto, K. (2016), From Social Security to social investment? Compensating and social investment welfare policies in a life-course perspective. Journal of European Social Policy, vol. 26, no. 5, 442459.

Kümpers, S. et. al. (2010), Prevention and rehabilitation within long-term care across Europe. Interlinks, Berlin.

Leech, N. and Onwuegbuzie, A (2009), A Typology of mixed methods research designs. Qual Quant, vol. 43, pp. 265-275.

Mahon, R. (2013), Social Investment According to the OECD/DELSA: A Discourse in the Making, Global Policy, vol. 4, no. 2, pp 150-159.

Mandag Morgen (2017); Sociale investeringer tager fart - millioner kan spares. Mandag Morgen, March, 2017, no. 12.

Midgley, J. (1999), Growth, Redistribution and Welfare: Toward Social Investment. Social Service Review, March, pp.3-21.

Morel, N. et.al. (2012), Towards a Social Investment Welfare State? Ideas, Policies and Challenges, Bristol, Policy Press.

Nolan, B. (2013), What use is ‘social investment’? Journal of European Social Policy, vol. 23, no.5, pp. 459-468.

Piven, Frances Fox (2015) Neoliberalism and the welfare state, Journal of International and Comparative Social Policy, 31:1, 2-9, DOI: 10.1080/21699763.2014.1001665

Sabato, S. and Vanhercke, B. (2014), About the baby and the bathwater: assess the European Platform against Poverty. Working Paper, 2014.09, ETUI. 
Smyth, P., and Deeming, C. (2016) The 'Social Investment Perspective' in Social Policy: A Longue Durée Perspective. Social Policy \& Administration, 50: 673-690. doi: 10.1111/spol.12255.

Socialministeriet (2000), Social Politik som investering. Socialpolitisk Redegørelse 2000, København, Socialministeriet.

Taylor-Gooby, P. (2008), The New Welfare State Settlement in Europe, European Societies, vol. 10, iss. 1, pp. 3-24.

Taylor-Gooby, P., Gumy, J. and Otto, A. (2015), Can 'New Welfare’ Address Poverty through More and Better Jobs? Journal of Social Policy, vol. 44, no. 1, pp. 83-104.

Vaalavuo, M. (2013), The Redistributive Impact of 'Old' and 'New' Social Spending. Journal of Social Policy, vol. 42, no. 3, pp. 513-539.

Vandenbroucke, F. and Vleminckx, (2013), Disappointing poverty trends: is the social investment state to blame? Journal of European Social Policy, vol. 21, no. 5, pp. 450-471.

Vliet, O and Wang, C. (2015), Social Investment and Poverty Reduction: A comparative analysis of fifteen European Countries. Journal of Social Policy, vol. 44, no. 3, pp 611-638. 
Acknowledgement.

This article has been written as part of Horizon 2020 project SPRINT supported by the European Union.

Further is acknowledged the support from Rasmus Holm in writing up the information from the focus group interview. 
Annex 1. Participants in the focus group interview

\begin{tabular}{|c|c|c|}
\hline Name: & Organisation: & Short Description: \\
\hline Tine Rostgaard & KORA & $\begin{array}{l}\text { Professor at KORA, the Danish Institute for Local and Regional } \\
\text { Government Research }\end{array}$ \\
\hline Bjarne Hastrup & Aldresagen & $\begin{array}{l}\text { CEO of } A \text { Eldresagen } \\
\text { (interest organisation related to elders) }\end{array}$ \\
\hline Arne Rolighed & $\begin{array}{l}\text { Danske Seniorer } \\
\text { and } \boldsymbol{A} \text { Eldremobilliseringen }\end{array}$ & $\begin{array}{l}\text { Vice Chairman of Danish Seniorer and Chairman of } \\
\text { ÆEldremobiliseringen } \\
\text { (interest organisations related to elders) }\end{array}$ \\
\hline Lisbeth Marie Grøndahl & DANSKE ÆELDRERÅD & $\begin{array}{l}\text { Health Political Consultant at DANSKE AELDRERÅD } \\
\text { (interest organisation related to elders) }\end{array}$ \\
\hline Lone Vasegaard & $\begin{array}{l}\text { DKDK and } \\
\text { Demensklinikken OUH }\end{array}$ & $\begin{array}{l}\text { Chairman of DKDK (Organisation working with Dementia) and } \\
\text { Clinical Nurse at the Dementia Clinic of Odense's University } \\
\text { Hospital }\end{array}$ \\
\hline Lene Juel Rasmussen & Centre for Healthy Aging & Managing director and professor at Centre for Healthy Aging \\
\hline Anne Dorthe Prisak & $\begin{array}{l}\text { Sundhedsfremmende } \\
\text { og Forebyggende besøg til ældre } \\
\text { (SUFO) }\end{array}$ & $\begin{array}{l}\text { Preventative Consultant } \\
\text { working in Aarhus Municipal }\end{array}$ \\
\hline Ulla Skjødt & University College Sjælland & $\begin{array}{l}\text { Associate professor at } \\
\text { University College Sjælland }\end{array}$ \\
\hline
\end{tabular}

